Gail L. Schumann

University of Massachusetts, Amherst

Cleora J. D'Arcy

University of Illinois, Urbana-Champaign

\title{
Plant Pathology Courses for Agricultural Awareness
}

Plant pathology has had and continues to have direct relevance and impact on everyday life. The science of plant pathology was born of famine in Ireland in the 1840s. Concerns about the effects of plant diseases on our lives are as relevant today. However, most people don't think about plant diseases, and there is considerable concern among plant pathologists about this lack of awareness and what it portends for the future of our discipline. How do we get the message to the majority of college students, who shy away from science courses in general and never consider taking a course that deals with agriculture? How do we develop an awareness of agriculture's impact on their daily lives? Should agricultural awareness be a required component of higher education now that most students live urban and suburban lives? Even in states where agriculture is a significant component of the economy, many students are ignorant of agriculture's importance. Today, only a very small minority ( 2 to $3 \%$ ) of the population produces our food. The need to educate citizens so that they can contribute to food and agricultural policies in a thoughtful and rational way is a critical challenge.

In addition, many departments are now facing new responsibilities for undergraduate courses in the competition for university resources. Can general education courses that explore agricultural issues help fulfill these requirements and, at the same time, benefit the discipline of plant pathology and the individual programs that sponsor these courses?

A number of departments have already initiated such courses in agri-

Dr. Schumann's address is: Department of Microbiology, University of Massachusetts, Amherst 01003-2420;

E-mail: schumann@pltpath.umass.edu

Publication no. D-1999-0319-01F

(C) 1999 The American Phytopathological Society cultural awareness. In this article, we describe our experiences at two institutions and what we believe these courses accomplish for the students and for the discipline of plant pathology. We also want to encourage more plant pathologists to participate in courses aimed at students who have never heard of plant pathology.

\section{Course Philosophy and Content}

The University of Massachusetts course, "Plant Diseases: Feast or Famine," was first taught in 1985. Three years later it was approved as a general education bio-

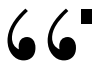

\section{Student Attitudes About the Course}

"This is a course that every student should be required to take before graduation. It allows you to appreciate the world around us. I will never look at it the same way."

"I am an English major scared to death to take a science course, and I loved this class. It was not necessarily easy, just very enjoyable."

"Despite the fact that the class is at night, I never felt sleepy!"

"I have never taken an ag class prior to this, and (this course) has definitely opened my eyes and made me appreciate people in the agriculture field!"

"Plant pathology was much more fascinating than I had anticipated."

"I was never excited about science before, and now I am."

logical science course. UMass general education requirements include three approved science courses. One of the courses must be in the biological sciences, one must be in the physical sciences, and students may choose either area for their third course. Theoretically, then, students could graduate with a single biology course. It is obviously impossible to properly educate someone in biology in a single course, but it is an interesting exercise to think about what the priorities should be. The UMass general education guidelines require that approved courses include the historical development of the science and its relevance to daily life, and should "foster critical thinking." We would hope that all courses foster critical thinking, but certainly plant pathology is a rich resource of relevant issues that require careful analysis before deciding on an acceptable solution.

Course requirements include three exams, four papers on controversial agricultural issues, commentary on two popular media articles, and a final exam (Sidebar 1).

The University of Illinois mandates general education in several areas. The "Plants, Pathogens, and People" course fulfills requirements in two of these: life sciences, under the heading of natural science and technology, and composition in a discipline. University of Illinois general education courses are designed 'to broaden students' understanding of human thought and achievement..., to develop their communication skills, and to enhance their critical thinking..." Life sciences courses must be introductory courses that present the "fundamentals of biological science," a challenge similar to that at UMass. Composition courses must include substantial writing assignments that "demand analysis and synthesis of the subject matter in the course." As at UMass, plant pathology has provided subject matter that can readily be adapted to fulfill all of these goals. Plants, Pathogens, and People was first taught in 1993 and has had full enrollment of 75 students every year since then. Course requirements include three papers (each with three drafts) on agricultural issues, six short in-class writing assignments, a midterm, and a final exam (Sidebar 1).

To many traditional plant pathologists, it may sound inappropriate or even ridiculous 
to spend time on such courses. Some might argue that separate courses should not be designed specifically for nonscience students. Many plant pathologists have had the relative luxury of teaching primarily graduate students, upper level undergraduates, and students who are preparing to make their living from plants and have a professional need for knowledge about plant diseases. These students know that their professional future depends on the information they learn.

Without getting into a detailed discussion of this issue, we suggest that the goals and approaches for general education science courses are very different. Science majors are beginning a lifetime of detailed learning about their subject. In contrast, nonscience students need a foundation in concepts. They need to develop the confidence to evaluate new information as it becomes available within the framework of those concepts, even though they are not professional scientists. Anyone who does not think this is a valuable enterprise should consider the inability of many people with advanced degrees in nonscience areas to rationally consider the benefits and risks of pesticide use and genetic engineering. When people feel ignorant about a subject, they tend to take conservative stances out of fear of the unknown and the inability to judge risk. Many controversial issues also have ethical dimensions that should have input from both scientists and nonscientists, who bring a variety of viewpoints to these complex problems.

\section{Why Students Take the Courses}

Before we suggest why students take these courses, we will consider why most students take only required science courses. Despite excellent efforts by talented high school teachers, many students retain little information from their high school biology courses. Students often see science as having no relevance to their daily lives. Worse, many students are intimidated by science and science courses. At Illinois, although some students in Plants, Pathogens, and People have taken several college biology courses and are looking for a course in which they can write about science, most students have had no science since high school and come to the course with some trepidation. At UMass, before registering in Plant Diseases: Feast or Famine, students have asked if it is "really hard" or "has a lot of science in it." With such a negative attitude toward science, these students probably skip the science section of the newspaper and cannot evaluate the television reports about pesticide residues, crop surpluses, and other issues related to agriculture. Perhaps if students learn to see biology every time they visit a grocery store, some of the more important principles would remain in their consciousness (Student quotes-1).
When we ask students why they enrolled, they give many different answers. Common responses at both institutions in approximate order of number of responses include "fulfills a requirement," "recommended by a friend," "sounded interesting," and "fit my schedule." The UMass course was offered for several years before it became part of the general education curriculum. Enrollment significantly increased when students were able to earn their science credits by taking the course. Courses that help students meet other requirements may be more likely to be successful at attracting students. In years when a campus poster campaign was possible, enrollment exceeded 50 students. Phone calls to the department office suggested that it was difficult for students to find the course registration information because they were looking under other biologyrelated departments.

At Illinois, students enroll in Plants, Pathogens, and People primarily to fulfill their composition requirement and secondarily to fulfill their science requirement. The fact that students can "double dip" is a significant factor in enrollment, given their tight academic schedules. Although the former Department of Plant Pathology has now merged with agronomy into the Department of Crop Sciences, students are still able to find Plants, Pathogens, and People on lists of general education

\section{Sidebar 1 - Sample Syllabi}

\section{"Plant Diseases: Feast or Famine"- 3 credits}

University of Massachusetts

Topics (approximately 1 week each):

The Irish Potato Famine and the Birth of Plant Pathology

Introduction to Fungi and Their Life Cycles

Pathogens and Quarantines

Bacteria

Genes and Genetic Engineering

Plant Disease Epidemics and Their Management

Pesticides

Soil, the Rhizosphere, and Soil-borne Pathogens

Fungi in Food: Natural Poisons and Gourmet Delicacies

Rusts

Dying Trees and Parasitic Plants

Viruses and More Recently Discovered Pathogens

Environmental Diseases and Problems

Plant Diseases in a Hungry World

Requirements:

$\begin{array}{lr}3 \text { exams } & 150 \text { pts. } \\ 4 \text { writing assignments } & 100 \text { pts. } \\ 2 \text { popular press articles with commentary } & 20 \text { pts. } \\ \text { Final exam } & 100 \text { pts. }\end{array}$

Enrollment:

26-57/ mean enrollment 40

Evenly split between first year and sophomore with few upper-class students.

"Plants, Pathogens, and People" - 3 credits

University of Illinois

Topics (1 week each):

The Irish Potato Famine

Introduction to Fungi

Pathogens and Quarantines

Bacteria and Genetic Engineering

Plant Disease Epidemics

Pesticides

Soil-borne Pathogens

Fungi in Foods

Rusts

Dying Trees

Viruses, Viroids, Phytoplasmas

Environmental Diseases

Plant Disease Management

Requirements:

3 macrothemes

6 microthemes

Midterm examination

Final examination

Enrollment:

67-76/ mean enrollment 71

Evenly split among sophomore, junior, and senior students.

$$
\begin{aligned}
& 300 \text { pts. } \\
& 100 \text { pts. } \\
& 250 \text { pts. }
\end{aligned}
$$$$
350 \text { pts. }
$$

A case history to illustrate important concepts The most important group of plant pathogens Our mistakes: decreased diversity, exotic pathogens Prokaryotic pathogens and crop improvement The hand of humankind is seen in epiphytotics What they do for us and to us and the environment

Tiny animals and other belowground pathogens Poisons and delicacies

Some plant pathogens need more than one host Epiphytotics in perennial woody plants

"New" plant pathogens

Not every disease is caused by a living pathogen

Past, present, and future 
courses published by the university on the World Wide Web and in the course timetables. Student word-of-mouth has also been a major factor in high enrollment, even though the course is only taught in the fall semester.

Communication with first- and second-year students in other colleges of one's own university may not be easy. Some universities offer crosslistings or web-based course publicity, but reaching nontraditional students can be time-consuming and difficult where these options do not exist. These are some real-world problems that occur when we try to attract nonscience students to a course listed under a discipline of which they are unaware.

\section{Benefits of the Courses for Nonscience Students}

General education students are particularly challenging to address because they have to be convinced at every lecture that science is interesting, relevant to their lives, and able to be learned. Our experiences with these nontraditional students have been both satisfying and frustrating. Many students in the general education courses do not yet have much direction in their lives. This gives us the opportunity to recruit talented urban and suburban students into the agricultural sciences. A small percentage of our students have actually gone on to become plant pathologists

\section{Student Attitudes on Writing} Assignments

"Writing papers (on issues) was beneficial because it didn't make the whole class all science and facts."

"I enjoyed learning and writing about topics that actually affected me."

"The writing assignments got me to think about important issues that I didn't know were important before."

"I enjoyed writing the papers, particularly because there was a clear progression and our work was continually evaluated."

"The practice in on-the-spot writing and writing for different audiences (was beneficial). I enjoyed having a specific audience, such as a congressman, to write for."

"The (paragraph length) writing exercises taught me how to be brief and to the point."

or pursued other areas of biology. To our disappointment, some first- and secondyear students are not yet ready to focus on academics. Even the best teaching efforts will accomplish little with them. Of course, there is the very large majority who will not become plant pathologists, but will leave with a better appreciation of where

\section{Sidebar 2 - Examples of Opinion Essay Topics}

\section{Quarantines and free trade}

How can you, as a legislative aide, educate your legislator about the importance of quarantines and their role in trade?

What are the effects of NAFTA on U.S. food producers? consumers?

Are quarantines an effective means to prevent spread of Karnal bunt? citrus canker?

Relative risk as demonstrated by the pesticide/organic situation

Would the food supply be safer if stores could only sell food that was grown "organically"?

Should natural food components and food "additives" be regulated in the same way?

What would you recommend to a friend who wanted to minimize dietary risk of cancer (What foods should they avoid? What should they eat?)

\section{Genetic engineering}

Are genetically engineered foods more or less likely to present dangers to consumers than those created through traditional breeding?

Should genetically engineered foods be labeled as such for consumers?

Should regulation for the release of genetically engineered plants be different than regulations for microorganisms?

\section{Food safety}

How can you minimize the potential for poisoning by microbial contamination in your own food and food preparation?

How can you as a (future) parent best ensure that your children have a safe food supply?

Cite and describe two examples of recent human poisonings from microbial contamination of food other than meat.

Choose 10 vegetables from a garden catalogue. Write why you chose each (color, taste, disease resistance, etc.) and then draw a garden plan in which you group the plants by family for crop rotation. (This is particularly successful with urban students who have never seen a seed catalogue before. Students who already garden enjoy it also.)

their food, fiber, and wood products come from and the constraints to their production. A number of students have kept in touch in the semesters following our courses by sending us clippings and articles, contacting us with questions for research papers in other courses, and by sending their friends to take our courses. Students who become teachers can have an enormous potential multiplier effect and reach additional students for many years to come.

Nearly every discussion of the weaknesses of modern higher education addresses the need for critical thinking and improved oral and written communication skills. Students early in their undergraduate careers can benefit greatly from trying to analyze information sources, to determine the biases each author brings to the work, and then to develop opinions that can be well-supported by materials judged to be reliable. Both of our courses require several papers to be written on various agricultural issues (Sidebar 2). Each of us assures the students that they will not be graded on their opinions, but on their ability to support their conclusions. We know that we have found a "hot" topic when the students' opinions are divided. The ability to evaluate source materials is difficult even for mature scientists. It can be overwhelming for undergraduates who have not yet discovered how inaccurate many reports are, especially those in the popular media. Internet sites represent a vast new source of materials that must be carefully evaluated before they are accepted as reliable sources of information.

Writing skills and critical thinking. Everyone despairs of the writing skills of students, but most people learn to write by writing. It is unfortunate that many early undergraduate courses at major land-grant universities are very large and do not lend themselves to writing assignments with faculty feedback. This is probably most true in science courses, which tend to have objective-style exams. Courses designed specifically for nonscience students can focus on their ability to develop rational opinions through writing assignments (Student quotes-2). When students are required to rewrite several drafts of their writing assignments, the students gain even more. Unlike creative writing assignments, these opinion papers can encourage students to hone skills in technical writing that will be useful in numerous future work environments.

Although teaching writing may seem daunting for plant pathologists, it is surprising how easy it is to help students improve without spending excessive time grading writing assignments. At UMass, the writing assignments are quite short (2 to 3 pages). Students are instructed to con- 
centrate on their ideas and writing quality rather than on filling multiple pages. Even short papers are enough to identify common errors in spelling, grammar, and sentence structure. After the first paper, the common errors are discussed, a list is provided, and students are warned that they will be graded more strictly in subsequent assignments. At the University of Illinois, each major paper is written three times, but only the final version receives a grade. Earlier drafts are evaluated in two ways. First, technical errors are noted by check marks in the margins. It is the student's responsibility to find and correct the errors, although the instructor is always willing to go through a paper line by line for a student who has difficulty with English. Second, three or four ideas to improve the paper are written at the end of the draft. These comments may focus on organization, introduction or conclusion, transitions, audience, factual content, support for opinions, or use of resources. Students respond positively to this approach, which helps them target specific areas for improvement rather than having comments written all over their work. It is surprising and rewarding to see how quickly the quality of writing improves when students' attention is focused on common problems in their writing.

Appreciation for the human aspects of science. Many students are of the opinion that science is a set of facts produced over time by nonemotional human beings who focus only on the design of the next experiment. From the earliest speculations on the causes of plant diseases (Roman rust gods), the acceptance of the Germ Theory (late blight and the Irish potato famine), and the mysteries of parasitic life forms (mistletoe in various mythologies), the human aspects of science are of great in- terest to students (Sidebar 3). Students can see scientists as "real people" when they hear how Charles Goodyear set up a workbench in debtor prison so that he could pursue his research on rubber, or how Bea Schwarz's identification of the fungus that causes Dutch elm disease was disbelieved because she was "just" a student! They are particularly interested in the idea that science has not developed in a straight line from one anticipated discovery to the next, but has been a series of leaps forward, backward, and off into dead-end alleys as paradigms shift and strong personalities rule certain areas of research.

Retention. One has to wonder why so little biology is retained from high school courses as we try to improve retention at the college level. First, of course, the students may have taken biology three or more years previously, which is a significant period of time to a typical undergraduate student who feels removed from the world of science. The debate on the best ways to educate biology students has gone on for decades. For example, without minimizing the importance of learning the detailed steps of mitosis and meiosis, one must wonder why it is so difficult for even many biology majors to make a simple statement about the function of each process. If this is true for biology majors, then we must be particularly careful about what we focus on for nonscience students so that the information will be retained and useful for them in their lives.

Active learning may help engage reluctant students and aid in retention. By introducing topics with familiar foods, historical events, and cultural aspects of plant diseases, students can be eased into the science behind them. Because we are concentrating on concepts rather than detailed knowledge, we can allow students to direct the discussions through their questions and opinions and still accomplish our goals. Topics such as genetic engineering and pesticide use can be introduced by asking students to discuss the controversial aspects and identify where they need to know more to understand the issue and develop an opinion. At the University of Illinois, students write short microthemes during class, which often serve as the basis for class discussion. Giving the students time to consider and express their opinions in writing leads to increased participation in the discussions. If students can be given the confidence that they too can read information and make reasonable judgments, they may be more likely to do so even after the class ends. Many first- and second-year students are excited that they can use their new knowledge to identify inaccuracies in media reports. The UMass course requires students to find and write commentary on two media reports related to the course to encourage these connections outside of class. All of these approaches encourage students to see that the instructor does not consider these controversies simple or their solutions obvious, and that our own opinions evolve and change over time.

Simple exploratory lab exercises offer more opportunity for questions, theories, and speculation. Opening students' eyes to biology and plant pathology that they can see every time they go shopping (Rhizoctonia sclerotia on potatoes) or go for a walk (powdery mildews and mycorrhizal mushrooms) may encourage them to remember class material and even share it with their friends or family. Visitors often accompany students to the UMass "fungus party," and some Illinois students discuss the diseases that can increase the cost of Thanksgiving dinner with their families. Students who come to believe

\section{Sidebar 3 - Examples of Subjects Particularly Interesting to General Education Students}

\section{Irish potato famine - the science and politics behind a human disaster}

The Irish potato famine includes almost every topic that one might want to discuss in a general education course, including: movement of food plants and pathogens around the world, the germ theory, the dangers of genetic uniformity and monoculture, the social and political aspects of food production and distribution.

Rust gods, St. Anthony's Fire, mistletoe - the connections between agriculture and religion

These examples demonstrate how observant ancient people were of the natural world and how they sought to understand and explain these phenomena and protect themselves from harm from plant diseases and food-borne poisons.

Genetic code/genetic engineering - the universal nature of genes

Any educated citizen needs to understand the basic structure and function of genes in order to appreciate and come to a reasonable opinion of what can be done, what should be done, and what should not be done.

Ergotism, mycotoxins - the existence of "natural" poisons and their effects on animals, including people

Most students have an idyllic and inaccurate view of the safety of the food supply of the past.

Pesticides - the diversity of chemicals this term includes, how much regulation already exists

The use of pesticides is a complex and controversial topic that deserves some analysis. Students rarely understand the concept of relative risk, the variety of chemicals grouped under this generic term, and how scientists determine appropriate regulations.

Parasitic plants - the complex interconnections between plants themselves

The ubiquitous existence of parasites, including plants that parasitize other plants, is an interesting lesson in natural history. Students again can see that ancient people were cognizant of the unusual attributes of these plants when they consider the role of mistletoe at Christmas.

Trees - how they grow and live for so many years, how we can protect them

It is important to appreciate the biological differences between plants and animals when learning about their diseases. Tree diseases are often easy to identify and usually easy to find on college campuses, giving students a daily reminder of plant pathology. 
that science is fun, interesting, and learnable have gained an important confidence that may help them in all aspects of their academic careers and may contribute to lifelong learning.

Forms of life and how they interact. One of the most valuable lessons we have found for such students is the disease triangle. Learned probably on the first day of most standard plant pathology courses, the idea of the interaction of organisms, as modified by their environment, is very enlightening to our students. It opens the door to a study of both the diversity of organisms (i.e., potential pathogens of plants) and their general systematic relationships. Perhaps for the first time, students can begin to consider how an organism is designated as a plant, an animal, or a fungus, and which organisms are more closely related to us. Once the types of organisms have been established, students begin to examine how they interact and how environmental conditions modify that interaction. In too many general biology classes, the various components are treated chapter by chapter without demonstrating the continuous interaction of organisms that makes biology so interesting and exciting. Examples from plant pathology are exemplary tools to demonstrate these interactions.

The dynamic interaction of plants and their parasites also presents the opportunity to examine basic genetics and the sources of genetic change. Some of the most dramatic stories of plant pathology are based on the initial meeting of plants and parasites that have not interacted before. This can lead to a discussion of how organisms change genetically, the sexual cycle, and its role in eukaryotic organisms whether they are diploid, haploid, or dikaryotic in their vegetative state. You can hook students on concepts by introducing them in intriguing ways. For example, every student who takes Plants, Pathogens, and People can tell you that the primary purpose of sex, for a fungus or a plant or a human being, is to create variability in the population. An understanding of the similarity of cellular processes of organisms is as important as what makes them different.

The idea of sexual and asexual reproduction is an important component of the study of many fungal pathogens, but may confuse students initially. They are, however, already familiar with asexual reproduction in plants through bulbs, tubers, cuttings, etc. The story of late blight can be used to compare the tubers and seeds of Solanum tuberosum to the zoospores and oospores of Phytophthora infestans. The relative role of each kind of propagule, the relative role of mutation in different kinds of organisms (i.e., macro- versus microorganisms), and the means of survival of each species can all be discussed.

The blueprints of life and how life evolves. If citizens are expected to make rational decisions about genetic engineering, they need to understand what a gene is and the basic process by which a gene is translated into a protein. All of the students have learned this basic information before, but few have retained it. It was too abstract or too removed from their daily experiences. A simple way to begin is to allow them to actually see DNA by swirling a mass of gram-negative bacteria in 3\% $\mathrm{KOH}$ until the cell walls dissolve, releasing the DNA. Students can string up amazing quantities of DNA in 20 seconds or so with nothing more than a slide and a toothpick (Fig. 1). It is particularly impressive when they can observe how small individual bacteria are as part of the exercise. Even though they have heard it before, students don't really appreciate the significance of the phrase "universal genetic code" until they see a transgenic tobacco plant glowing from the presence of the firefly luciferase gene. Most of them are disturbed about the idea of "foreign" genes in their food supply because they don't understand that diverse organisms share many similar or nearly identical genes. Evolutionary studies based on accumulations of mutations of common genes over time are of great interest. Students need to appreciate both the power and the limitations of a single gene.

Parallels to human health. The parallels between plant health and human health are another valuable aspect of courses designed for nonscience students. Very few undergraduates understand the difference between a virus and a bacterium, not to mention fungi. They do not appreciate the limited role of antibiotics in the treatment
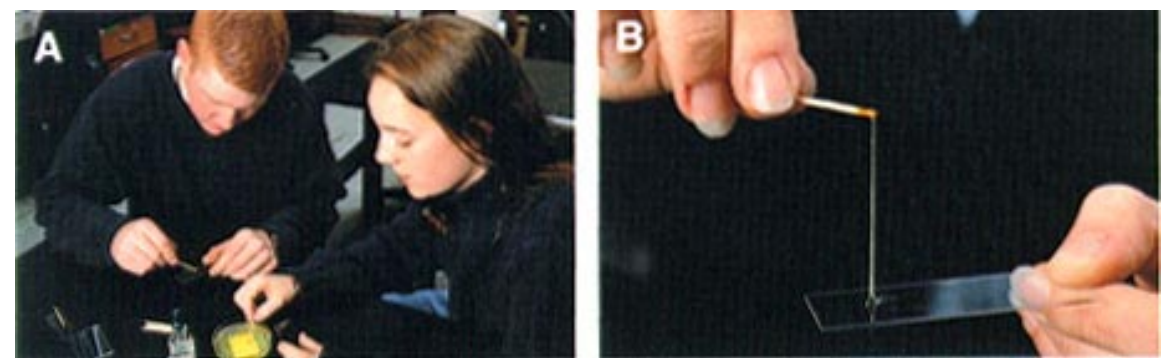

Fig. 1. (A) The cell walls of gram-negative bacteria will dissolve in $3 \% \mathrm{KOH}$, allowing students to quickly string up quantities of DNA with a slide and a toothpick. (B) Closeup. Courtesy G. L. Schumann. of diseases and how their misuse can lead to resistance. Koch's postulates are an interesting vehicle for discussions not only of proving pathogenicity of new plant pathogens, but also for human pathogens such as the HIV virus. Antibody-based home diagnostic kits for pregnancy and other medical tests are becoming increasingly popular. These can be explained and easily demonstrated in the classroom using commercial kits for plant pathogens (Sidebar 4).

Agricultural awareness. In the past 15 years, only one student in the UMass course has recognized a potato plant on the first day of class, despite the high concentration of citizens of Irish heritage in Massachusetts. The number of students in the University of Illinois course who can explain why seed corn is often red or green is depressingly small for a corn and bean state. Even though most college students have little knowledge of agriculture, they are no less dependent on the food supply than people were when they first began to cultivate crops. Where have major crops come from? Can this food base be expanded? It is fairly easy to find posters about "saving the rain forest" on most college campuses, and many students have a sense that this is important, but few see its direct impact on their lives. An examination of the centers of origins of the major crops and the concentration of biodiversity in the Tropics is an excellent way to begin a discussion of biodiversity and its importance in ecosystems. A recent issue of "Diversity" put the following quote from U.S. Vice-President Gore on its cover: "The single most strategic threat to the

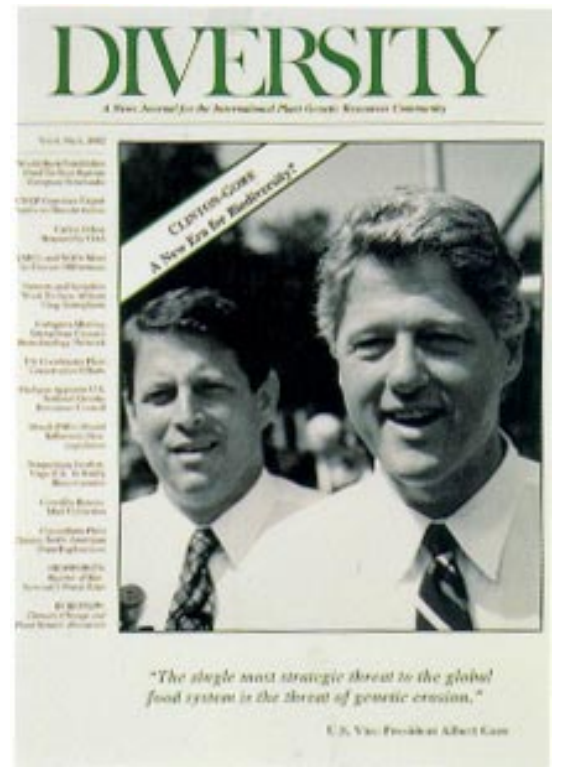

Fig. 2. "The single most strategic threat to the global food system is the threat of genetic erosion." How many educated people could express a reasonable opinion on this issue? Used by permission of Diversity and the Presidential Inaugural Committee. 
global food system is the threat of genetic erosion." (Fig. 2). How many college-educated people could give a reasonable explanation of what genetic erosion is and where and why it is happening?

An appreciation of the role of human beings in the world ecosystem should be a focus of biology courses for nonscience students. Food production is affected by policies on land use, water use, and population, all of which are governed by politicians more than biologists. All educated people should have some understanding of the constraints to food production, so that their roles in determining these policies are rational. The direct role of producers in management of plant diseases can be

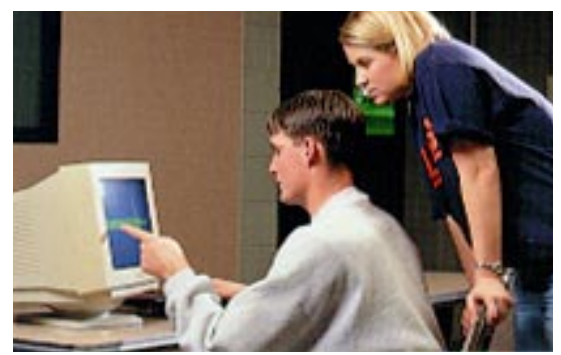

Fig. 3. Students use a computer disease assessment training program called DISTRAIN to improve their estimations of the area on a leaf that is affected by disease. Courtesy C. J. D'Arcy. simulated for students by having them try their hand at disease assessment training programs, such as DISTRAIN (J. R. Tomerlin and A. Howell. 1988. DISTRAIN: A computer program for training people to estimate disease severity in ce3). Other roles of people in plant diseases real diseases. Plant Dis. 72:455-459.) (Fig.

are easily demonstrated in the movement of plants and pathogens from their centers of origin to new lands. Travelers should understand the need for quarantine regulations, so they will cooperate with them (Fig. 4).

Students should be made aware of the benefits and risks of the many aspects of

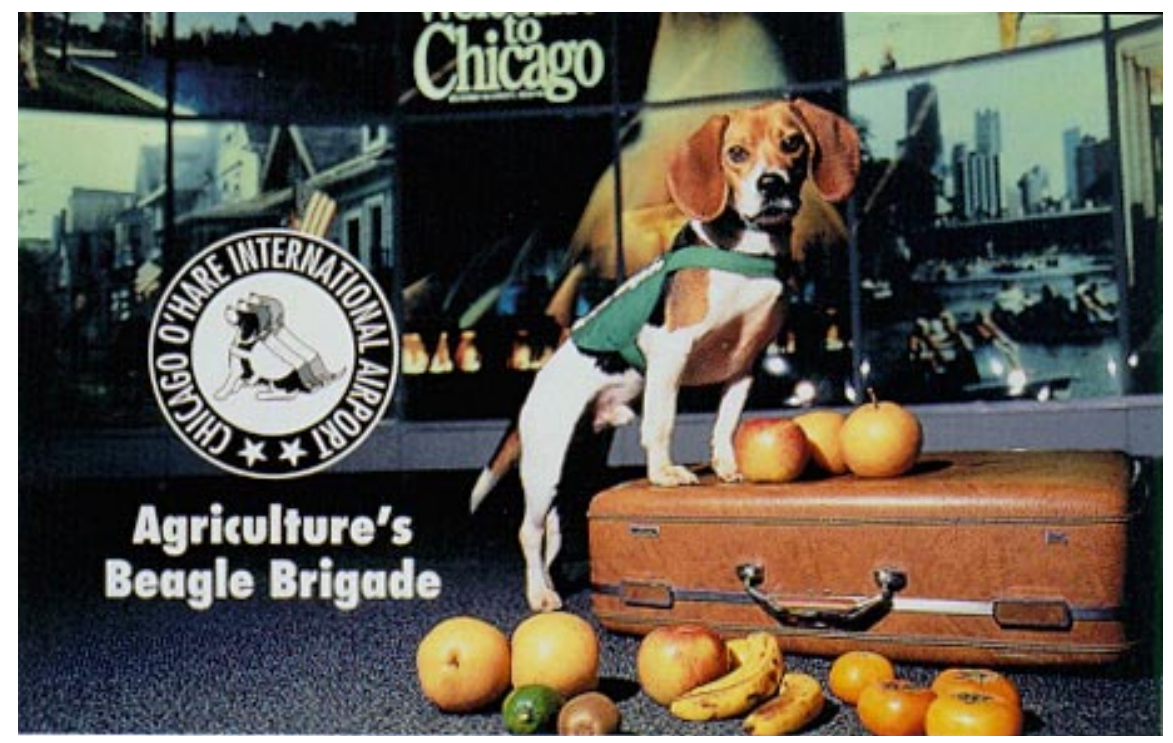

Fig. 4. Beagles are trained to help detect illegal fruits and vegetables at ports of entry. Citizens with agricultural awareness understand the importance of quarantine regulations and may be more likely to cooperate. Courtesy USDA-APHIS.

\section{Sidebar 4 - Easy Classroom Demonstrations}

Although neither course described in this article has a formal laboratory component, we bring as many materials and demonstrations as possible to class to give students a hands-on opportunity to experience plant pathology.

Potatoes - What is a tuber? What is an "eye"? Why are the sprouts better developed at one end? Why do tubers turn green? Why shouldn't you eat the green parts? Do potatoes produce flowers and seeds?

Grocery store biology is effective because students will see the same materials every time they go shopping. The materials are inexpensive, so students can explore and discover things they had not noticed before. Use of tubers is an easy way to introduce discussions of genetic uniformity, asexual reproduction, where crops came from, etc.

Microbes in the environment - Give each student a petri plate with nutrient agar and allow him or her to contaminate it. Display sealed plates at the next class and point out bacteria and fungi.

The ubiquitous presence of microorganisms is an important lesson. Students can examine colonies of bacteria and fungi to begin discovering their similarities and differences.

"Fungus Party" - Display the variety of edible and toxic fungi, including Botrytised wines, blue cheese under a dissecting microscope, camembert/brie cheese, corn smut, Aspergillus and foods such as peanuts, edible and poisonous mushrooms, and yeast.

Throughout history, observant humans have reaped the benefits of what must have originally been accidental contaminations of cheese, grape juice, and flour. When students see how commonplace these fungi are in our diet, they seem less foreign and intimidating.

Observation of Rhizoctonia mycelium - Cut sclerotia from grocery store potatoes and place them on water agar plates to allow mycelial growth, which can be observed directly on a microscope stage and/or an overhead projector.

Introductory students have a more difficult time with the concept of a mycelium-based fungus than with the more familiar plants and animals. Students can observe the rapid colonization of the agar plate surface in a few days and come to the next class with theories and questions about the nature of fungi.

Stringing DNA - Dissolve cell walls of gram-negative bacteria in $3 \% \mathrm{KOH}$ on a slide and string the released DNA on a toothpick.

This experiment can be used to initiate discussions on a number of different topics from the nature of DNA, differences between genes in prokaryotes and eukaryotes, the basic biology of bacteria, the discovery of the gram-negative and gram-positive bacteria and differences in cell wall structure, and taxonomic features of bacteria.

ELISA kits - Allow students to try kits such as those used for Pythium, Rhizoctonia, or aflatoxin and discuss the uses of ELISA in human medicine.

Discussions can include the benefits and limitations to these tests for a safe blood supply and rapid diagnosis of HIV or Lyme disease. The role of the immune system in animals and what parallels exist in plants are also interesting to students.

Grocery store waste - Prepare a display of the produce discarded by a local store in a single day and discuss why this happens.

The continual competition between microorganisms and humans for food is an interesting topic for class discussions. The role of postharvest problems in various regions of the world greatly affects food storage. What biological, chemical, and physical methods exist for reducing these losses? 
modern agriculture, including monoculture and vegetative propagation. One effective way to talk to urban and suburban students about monoculture is through the tree disease stories such as Dutch elm disease and chestnut blight. In the eastern United States, many students live in cities and towns with an Elm Street or Chestnut Street but without any trees of those species. They will notice the rows of maples and oaks that line their streets today and come to class wondering about their vulnerability in the future. In the Midwest, students can see the continuing relentless spread of Dutch elm disease in the few remaining trees in their towns and cities. Examples like this allow students to visualize the potential hazards of monocultures.

Demonstrating relevance. Students who are alienated from science need some convincing that it has relevance to their lives. At the same time, we believe that seeing practical applications of abstract principles may help students understand and remember the principles and see their applications in other realms. One of the most rewarding experiences we have is when a student describes a weekend or holiday discussion with a parent or grandparent in which the student passed on some of the practical information learned in our classes. Plant pathology provides many opportunities to teach "grocery store biology," which they may remember long after the class is over. A display of all the rotten fruit and vegetables discarded that day from a local grocery store will long be a vivid reminder of the fact that we waste more than one-third of the food we work so hard to produce (Fig. 5).

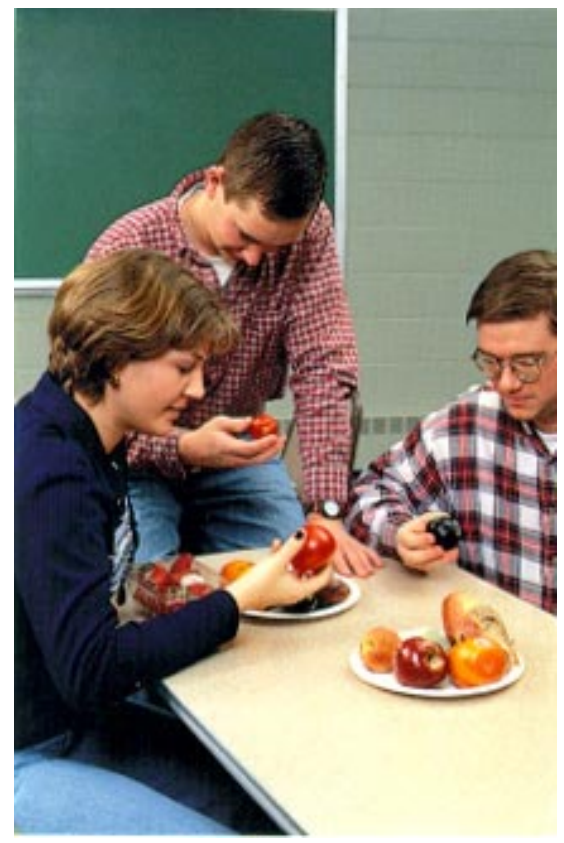

Fig. 5. Students examine one day's discards from a local grocery store to emphasize the fact that about one-third of the food we produce is wasted. Courtesy C. J. D'Arcy.

\section{How Plant Pathology Helps Reach Nonscience Students}

It is probably not necessary to list the many interesting stories from plant pathology that can be used to accomplish the twin goals of basic biological literacy and agricultural awareness, but we will briefly discuss some of the topics that have been most successful in our classes. First, everyone is interested in food and food safety. Students are fascinated to learn where various crops originated and how they came to be dominant crops in certain areas. A well-known example is the origin of coffee in Ethiopia, its nineteenth century production in Ceylon (now Sri Lanka), Indonesia, and other Southeast Asian countries, and its current predominance in Latin America. Every student knows the slang term "java" for coffee, but few even know where Java is, and no one has yet known how tea became the social drink of the British following the coffee rust epidemics in that part of the world.

Education in relative risk is invaluable for students, and plant pathology provides excellent opportunities for them to understand the concept. At Illinois, students routinely place the risk of death due to pesticide exposure above that due to playing football or receiving vaccinations, both of which are actually more hazardous. Currently, the role of fruits and vegetables as a source of human-pathogenic bacteria is a popular media topic. Students can learn the source of these bacteria, which foods are at higher risk for contamination, possible controls, and how the food system contributes to the problem. Mycotoxins are ubiquitous in our food supply, but few students have heard of them or know what controls and regulations are in place to protect us (Fig. 6). These two examples can then be examined relative to the issue of pesticide residues. They also present the opportunity to consider whether "natural" really means "safe." Different human beings set their personal safety standards at different levels, but these examples are effective at demonstrating that scientists who work in food safety do not dismiss the potential health risks of pesticide residues but rather examine them relative to other food safety issues.

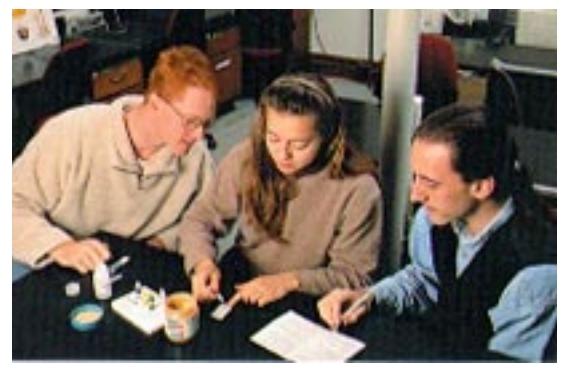

Fig. 6. Students test peanut butter from home for aflatoxin using a commercial immunoassay field kit. Courtesy G. L. Schumann.
Students find the history of science and food interesting. The cultural aspects of what people will and will not eat, what foods were available before the biological exchange between the New and Old Worlds, and religious beliefs linked to agriculture and pathogens are fascinating to students. They are impressed with how much plant pathology people figured out through their observations of crops and how that was interpreted in their customs. The red and black color symbolism in the animal sacrifices to the Roman rust gods, the prayers and hospitals dedicated to St. Anthony in hopes of warding off the effects of ergotism, and the mystical significance of mistletoe in many European and Scandinavian mythologies all originated with people who lived a life observing plants daily rather than sitting inside watching television (Fig. 7). The barberry laws, first passed in 1660 in Rouen, France, and also found in the early laws in the British colonies in North America, predated a scientific understanding of the heteroecious life cycle of Puccinia graminis by nearly 200 years.

Most students are familiar with the role of human diseases that followed the invasion of the Western Hemisphere by Europeans. It is a lesson of particular interest to UMass students because our town was named for the infamous Jeffrey Amherst who helped quell "problems" with the local Native Americans by giving them blankets contaminated with the smallpox virus. They are impressed that plant diseases have played similar roles in human history. Very few are aware that the Irish potato famine was caused by a new and specific fungal disease of potatoes or that ergotism was such a significant disease for many centuries in European history.

The potential for biological warfare is another popular topic in the media at the moment, but few students have considered whether our crops are as vulnerable as we are. Some of the most dramatic stories of plant pathology come from the introduction of new pathogens to unprepared host plants. The particular vulnerability of large expanses of single species grown perhaps from vegetatively propagated sources or highly genetically uniform seed is easy for them to understand. It is important, however, to emphasize why we have gone to this kind of agriculture and to consider the lives of people who are dependent each year only on the food they have grown themselves.

Students are more knowledgeable about human health than plant health, but it is disturbing how limited even that awareness is. The discussions of diagnosis, epidemiology, and management of plant diseases lead to many interesting questions and discussion of human health problems. Some of the most valuable insights seem to come from actually considering the biology of the pathogens and the kinds of ad- 
aptations they must make for dispersal, infection, and survival in the absence of a host. When students start thinking about these subjects in plant diseases, they automatically start thinking about their own potential pathogens and become more aware of what kinds of activities are likely to lead to disease.

Genetic engineering of plants is another area where the methods and results are already far beyond those accomplished for animals. Because this section of the course requires a basic understanding of gene structure and function, it also leads to discussions of mutation, potential for mutation repair, and what is and is not acceptable in human genetic manipulation. The plant discussions are also important to students because they are trying to decide if genetically engineered crops are safe to eat or should be labeled for consumer choice.

Because so many plant pathology examples directly affect the lives of students and, in addition, lead to connections with human health, plant pathology is an excellent vehicle to demonstrate the interest and concern of scientists about the quality of life. The fact that we acknowledge that many of these questions are difficult to answer and have a variety of acceptable answers helps to alter the stereotype of the socially irresponsible scientist.

\section{Benefits to Potential Instructors}

Compared with teaching traditional plant pathology students, we have found that teaching nonscience students is much more challenging and, at times, spectacularly rewarding or deeply frustrating. The successes, however, are more gratifying because many students actually have a lifechanging experience when they open their minds to the fascination of the biological world. Instructors in these courses have the opportunity to expose students to new ideas and to diminish their fear of science. Instructors can help students develop an appreciation of science, especially agricultural science, and may even attract a student or two into plant pathology. Finally, and perhaps most importantly, these instructors put a human face on science. We also have found that teaching general education courses helps keep us alert to the daily impact of our science. It is remarkably easy to find newspaper articles and television programs that discuss issues relevant to plant pathology courses for nonscience students. In research, we tend to focus our questions on specialized topics. It is fun to teach a class in which we can discuss a wide range of "big" questions.

\section{Benefits to Departments Offering Such Courses}

Potential instructors of nonscience student service courses may worry that there is a lack of value placed on the teaching of introductory courses in general and non- major and nonscience student courses in particular. Faculty members who have not taken on this challenge may suffer from the misconception that such courses require little thought or effort.

Luckily, these attitudes are changing, slowly at some institutions and more quickly at others, depending on the specific campus politics. Almost universally, plant pathology departments are being asked to participate in more ways in the undergraduate curriculum. In some cases, they may contribute to the general biology curriculum. Many of the students taking general biology courses are not planning to become biology majors. Therefore, a contribution to the curriculum for nonscience students who need biology credits may be welcome. This may help relieve the burden of excess students in the introductory general biology courses and allow those courses to be more focused for people seriously planning a future in biology. Alternatively, plant pathology courses may fulfill requirements in other general education areas, such as composition. Again, this relieves the burden on the traditional suppliers of writing courses, such as English and history departments. There is always the potential to recruit students into agricultural biology or even plant pathology, but the primary goal should be that students will develop an agricultural awareness and will view media reports with a more skeptical eye and a more open mind. Increased student credit hours for the plant pathology department is a more immediate benefit that has an increased importance and significance in many of today's universities.

\section{Benefits for the Discipline of Plant Pathology}

If we consider the future of plant pathology, we may wonder who is going to do the science and who is going to pay for it. With fewer plant pathology departments and programs, how will potential students even hear about the field? How can we reach potential students among racial and ethnic minorities who are underrepresented in plant pathology?

How can we interest urban and suburban students of all kinds who do not listen to farm reports on the radio or are unaware of the breadth of science conducted by plant pathologists? Plants remain an important component of urban areas, and many positions for plant pathologists are available in

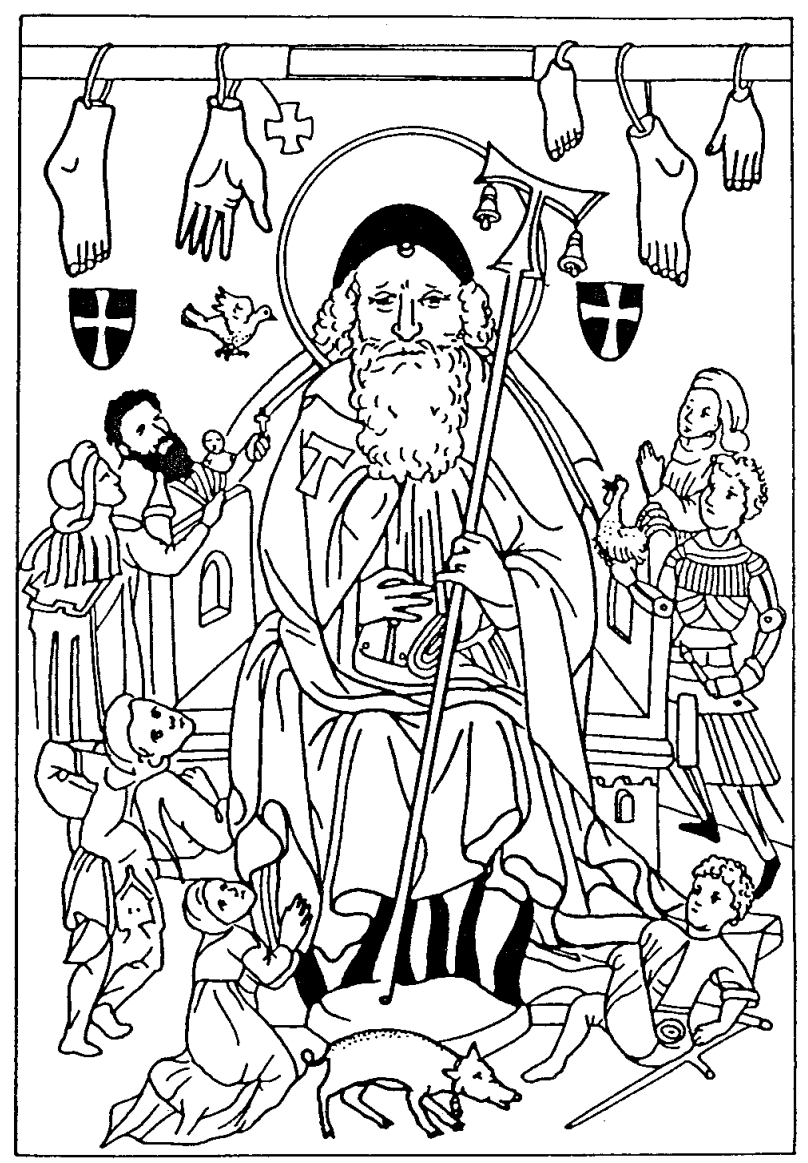

Fig. 7. Saint Anthony. Redrawn from a woodcut made in Germany about A.D. 1215. Note the hands and feet hanging from the bar. Ergotism often causes constriction of the peripheral blood vessels, resulting in gangrene and loss of extremities. Reprinted from G. L. Schumann, 1991, Plant Diseases: Their Biology and Social Impact. American Phytopathological Society, St. Paul, MN. 
all aspects of the green industries, including turfgrass, ornamentals, and nurseries. The role of plant pathologists in nontraditional undergraduate courses can help maintain an awareness of the discipline of plant pathology even when specific departments and programs have been incorporated into multidisciplinary academic units.

Another important concern addressed by these courses is the continuing support for plant pathology teaching, extension, and research programs. In other words, will an urban general public continue to provide adequate funding to maintain the discipline in times of food surpluses? Will the public retain the land-grant mission of our universities or will food production be viewed as just another private enterprise?

Why is the public so reluctant to support agricultural research? First, food is cheap and plentiful. Most news reports are about surplus problems. People in general are suspicious of science and technology they do not understand. They don't have the educational tools to judge the relative risks of methodologies such as pesticide use and genetic engineering. Many students do not see a role for themselves in providing major input into complex and controversial decisions. Most of today's legislators,

\section{What Students Will Remember or Found Most Surprising}

"Over the past two years I have lived nine months out of the year in Corn Country. As a native New Yorker my knowledge of agriculture was next to nothing. To answer the question,

'What have I learned in this course?'

is easy. Ninety-five percent of my total agricultural knowledge has come from (this course)."

"The interesting historical and economic facts. I impressed my husband with the chestnut blight story!"

"Throughout this course (I have learned) how the actions of people can strongly influence the course of a plant disease."

"(I learned) that sometimes natural things are more toxic than pesticides and other chemicals. I must say that before this class I was pesticide phobic."

"The lack of genetic diversity in a crop can have devastating effects."

"The most surprising thing I learned about this class was that I was actually very interested in the topic. I found out something new every day." judges, lawyers, and citizens were nonscience students. Scientists are paying the price for reducing access to a basic biological literacy for all educated people.

Courses aimed at nonscience students are an investment in the future of plant pathology. If every college student graduated with some level of agricultural awareness and comfort with the basic principles of biology, we would be able to reach them as educated citizens for discussion of new and current agricultural issues (Student quotes-3). If we don't make this effort when they are students, we will meet up with them again later as legislators, judges, voters, and taxpayers incapable of making reasoned evaluation of biological and agricultural issues.

Never in history has the knowledge of science been more important in society. Never in history have most people been so removed from the production of their food. As plant pathologists, we are aware of the potential problems and crises that may threaten a stable food supply for a growing population. It is our responsibility to help everyone participate in the decisions that will do no less than affect our continuing existence on earth.

\section{Resources}

\section{Books}

Avery, D. T. 1995. Saving the Planet with Pesticides and Plastic. Hudson Institute, Indianapolis, IN.

This book presents many interesting facts and references to support the use of high-input agriculture on the most productive land as the most efficient way to produce food and maintain wildlife and biodiversity. Certain to stimulate class discussions.

Carefoot, G. L., and Sprott, E. R. 1967. Famine on the Wind. Rand McNally \& Co., Chicago.

A fascinating and highly readable treatment of the social, political, and biological stories of the most famous plant disease epidemics.

Diamond, J. 1997. Guns, Germs and Steel: The Fates of Human Societies. Norton \& Co., New York.

An evaluation of how the presence of plants and animals that could be domesticated and the environment of early people played key roles in the development of civilization in various regions of the world.

Harlan, J. R. 1992. Crops and Man. American Society of Agronomy, Inc., Madison, WI.

An interesting report on some of the most important food crops and their influence on history.

Holmes, F. W., and Heybroek, H. M. 1990. Dutch Elm Disease, the Early Papers: Selected Works of Seven Dutch Women Phytopathologists. American Phytopathological Society, St. Paul, MN. Translations of the early research papers on Dutch elm disease.

Hudler, G. W. 1998. Magical Mushroom, Mischievous Molds. Princeton University Press, Princeton, NJ.
An entertaining and accurate treatment of the role of fungi in our lives written expressly for nonscience students.

Keller, E. F. 1983. A Feeling for the Organism: The Life and Work of Barbara McClintock. W. H. Freeman \& Co., New York. A wonderful portrait of an extraordinary scientist. It examines the human side of her life as a scientist as well as the difficult circumstances in which she had to work because of her sex. Includes readable accounts of her Nobel Prize-winning work in genetics.

Large, E. C. 1962. The Advance of the Fungi. Dover Publications, New York.

The classic account of the early days of plant pathology and microbiology. Written in the expressive language of old science.

Matossian, M. K. 1989. Poisons of the Past: Molds, Epidemics, and History. Yale University Press, New Haven, CT.

Matossian is a historian who has studied the connections between mycotoxins and ergot in the diet and witchcraft, the French Revolution, and historical birth rates in Europe.

Mayle, P. 1991. Toujours Provence (Chapter 7 on truffle hunting). Vintage Books, New York.

Essentially a travel book, the chapter on truffle hunting will interest students.

National Research Council. 1996. Carcinogens and Anticarcinogens in the Human Diet. National Academy Press, Washington, DC. A detailed analytical summary by a panel of distinguished scientists on what is known and not known about carcinogens and anticarcinogens in the diet. Many useful references.

Postgate, J. 1992. Microbes and Man. Cambridge University Press, Cambridge.

A classic account of the role of microorganisms in human history with an emphasis on medically important species. 
Sayre, R. M. 1994. Art in Phytopathology. American Phytopathological Society, St. Paul, MN.

A portfolio of drawings by Nathan Cobb, the father of U.S. nematology, with commentary about his life and times.

Schumann, G. L. 1991. Plant Diseases: Their Biology and Social Impact. American Phytopathological Society, St. Paul, MN.

This textbook was written expressly for the general education plant pathology course taught at the University of Massachusetts.

Viglierchio, D. R. 1991. The World of Nematodes. University of California, Davis.

A very readable account of the many roles of nematodes in the world with an emphasis on animal and plant parasites.

Woodham-Smith, C. 1962. The Great Hunger. Harper and Row, New York.

A historical account of the Irish potato famine. Very little biology of late blight is described, but the human tragedy and its political and social causes are well described.

\section{Videotapes}

Big Fears, Little Risks. 1989. Narrated by Walter Cronkite. American Council on Science and Health. Film Counselors Associates, Inc., 447 W. 45th St., New York.

This video gives perspective to the exaggerated fears of health effects of industrial contaminants in the environment. An excellent film to stimulate discussion because it is contrary to most reports in the mass media.

Dutch Elm Disease and the American Elm. D. M. Eastburn, C. J. D'Arcy, and L. McKee. American Phytopathological Society, St. Paul, MN. In production.

A video designed especially for students in general education plant pathology courses. It addresses the history of the introduced fungus that killed millions of elms, attempts to control the epidemics, and how the monoculture of elms along city streets contributed to spread of the disease.

Fungi: The Rotten World About Us. 1981. BBC Bristol Natural History Unit. Films Incorporated Video, 5547 Ravenswood Ave., Chicago.

A video that covers nearly every important role of fungi from the late blight epidemic to mycotoxins to mycorrhizae in a colorful and entertaining way.

Late Blight and the Irish Potato Famine. 1996. D. M. Eastburn and C. J. D'Arcy. American Phytopathological Society, St. Paul, $\mathrm{MN}$.

A video designed especially for students in general education plant pathology courses. It addresses the biology as well as the social and political history behind the Irish potato famine and the birth of plant pathology and the germ theory.
Of the Earth: Agriculture and the New Biology. 1988. Industrial Biotechnology Association, Venard Films, Ltd., East Peoria, IL. A video that addresses some of the fears people have about biotechnology. Several scientists discuss why the new methods are important, and the basics of genetic engineering using Agrobacterium tumefaciens are demonstrated. Although a little dated, it is a useful introduction to class discussion.

Rachel Carson's Silent Spring. 1992. The American Experience. PBS Videos, 1320 Braddock Pl., Alexandria, VA.

A portrait of Rachel Carson, the individual, and the concerns about pesticides that played a key role in the beginning of the environmental movement. Useful to stimulate class discussions.

Seeds for Tomorrow. 1985. Nova Program. Coronet Film and Video, 420 Academy Dr., Northbrook, IL.

This video addresses the issue of the loss of genetic resources, especially those of crop plants in their centers of origins. On-site film from around the world portrays the very human side of the future of our crop plants and food supply.

When Ireland Starved. 1992. Celtic Video Inc., 141 E. 33rd St., New York.

Made in Ireland, this is a public television style historical video that uses old drawings as well as film from the famine sites as they are today. There is little of the biology of late blight, but it is a useful resource about the famine.

World Population. 1990. Zero Population Growth, Inc., 1400 16th Street, N.W., Suite 320, Washington, DC.

A video that explores the issue of population growth.

\section{Web Sites}

APSnet: www.scisoc.org

A quickly changing resource that currently includes an illustrated lesson on late blight as well as a series of feature articles on important topics related to plant diseases that can be read by nonspecialists.

Plant Pathology Internet Guidebook: www.ifgb.uni-hannover. de/extern/ppigb/ppigb.htm

The ultimate resource for finding anything related to plant pathology and integrated pest management.

Plants, Pathogens, and People: www.extramural.uiuc.edu/PPP/ A web site developed to supplement the general education course at the University of Illinois. It currently has modules on late blight and Dutch elm disease.

Tom Volk's Fungi: www.wisc.edu/botany/fungi/volkmyco.html A wonderful collection of images, fungal portraits each month, and a list of harmful fungi for Thanksgiving and beneficial fungi for Christmas.

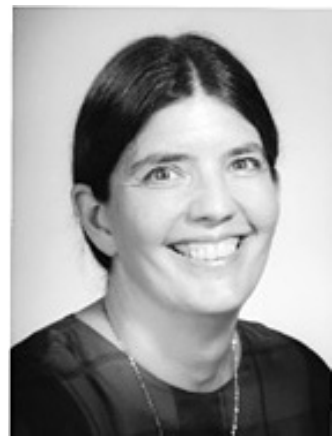

\section{Gail L. Schumann}

Dr. Schumann is associate professor of plant pathology in the Department of Microbiology at the University of Massachusetts at Amherst. She has a B.S. degree in botany from the University of Michigan and M.S. and Ph.D. degrees in plant pathology from Cornell University. In addition to the course described in this article, she teaches courses in general plant pathology, turfgrass diseases, and integrated pest management. She has extension and research responsibilities in turfgrass pathology.

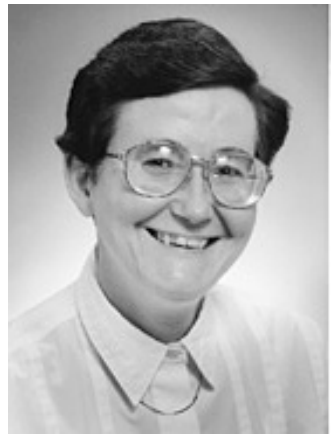

\section{Cleora J. D'Arcy}

Dr. D'Arcy is professor of plant pathology and teaching coordinator in the Department of Crop Sciences at the University of Illinois at Urbana-Champaign. She has an A.B. degree in biology from Harvard University and M.S. and Ph.D. degrees in plant pathology from the University of WisconsinMadison. In addition to the course described in this article, she teaches a seminar course for all seniors in her department, a graduate course on professionalism and ethics in science, and a course on teaching for new faculty members in her college. She has research responsibilities in plant virology. 